\title{
Asian English Literature's Midterm Examination Maternal Instinct Depicted in Verena Tay's Broken
}

\author{
Ruly Indra Darmawan \\ rulyindra33@gmail.com \\ Sanata Dharma University
}

\begin{abstract}
The role of women created a lot of controversies in feminist movement. Several feminists in first wave think that maternal instinct is a form of women's oppression, alongside with bureaucratic state and capitalism. This study aims to analyze how maternal instinct is depicted in one short story which has South East Asia as a setting of place because this maternal instinct has became one of the most debatable issues in feminist study until nowadays. This study is qualitative data. The main data is a short story entitled Broken. This short story was included in anthology of Asian short stories entitled A Rainbow Feast. One thing which becomes uniqueness in Broken that picks my interest is how this novel exploits woman acts and habits in different way than any other novel. The result show that the depiction of maternal instinct in Kalimantan ghost, Pontianak with Thailand ghost which is usually called Mae Naak. Both of them, according to the urban legend are woman ghosts which were died when they carried their baby. The difference is Mae Naak, which is usually made as main character in Thai theater, has a positive image as a ghost who still pampers her baby, very different with Pontianak image in which always devours her baby right after her resurrection.
\end{abstract}

Keywords: The role of women, short story, Verena Tay's Broken, ghost.

\section{INTRODUCTION}

Maternal instinct can be seen in every woman. This kind of instinct is highly related with how woman shows her love to her kids. This role of women created a lot of controversies in feminist movement. Several feminists in first wave think that maternal instinct is a form of women's oppression, alongside with bureaucratic state and capitalism $^{1}$. Those feminist such as Kate Millet, Juliet Mitchell, Shulamith Firestone, and also Betty Friedan insist that desanctification of family and also demystification of motherhood is a must. Those arguments were strengthened by several feminist in the mid-1970s by examined the relations between patriarchy and capitalism. They saw family as a manifestation of capitalism. Family, according to those feminists, reproduces capitalism inside the house in which

\footnotetext{
${ }^{1}$ Dietz, Mary G. "Citizenship with a Feminist Face: The Problem with Maternal Thinking." Political Theory 13.February (1985). p. 19
}

oppress and subordinate women on their daily basis.

It seems that those arguments above were based on how society saw a woman. In the past, the moves of woman were totally restricted in every side of the world. The roles of women either in patriarchal system of family structures also outside the house were also constituted by anti-feminist point of view. Woman typically had a little access to education, political, and also economic power. First-wave feminist saw those restrictions as a symbol and manifestation of oppression. The oppression was mostly done inside family circle where wife was prohibited by her husband to do any jobs or activities outside house.

But in recent years, the defender of family appears from feminist side. They think that maternal instinct empowers the woman role inside the family and society. Among those pro-family feminists, there are two prominent figures who are Jean Bethke Elshtain and Sara Ruddick. Those profamily feminists were focused on the social practices of mothering and also metaphysical attitudes which are shown by woman inside family circle. Sara Ruddick argues that maternal thinking can be 
promoted to be an antidote to maledominated culture ${ }^{2}$. Supporting Ruddick's statement, Jean Bethke Elhstain states that the old-feminists were suffering matriphobia. They brought out and connected several political implications of maternal thinking. Also that matriphobia was used as an excuse to restructure political consciousness on one basis in which by Elshtain was called social feminism. They claimed that mothering is one kind of dimension of women's experience. Furthermore, mothering is necessary to show gender identity of woman as well as defend the feminist's political consciousness.

In this essay, I want to analyze how maternal instinct is depicted in one short story which has South East Asia as a setting of place because this maternal instinct has became one of the most debatable issues in feminist study until nowadays. The main data is a short story entitled Broken. This short story was included in anthology of Asian short stories entitled A Rainbow Feast. One thing which becomes uniqueness in Broken that picks my interest is how this novel exploits woman acts and habits in different way than any other novel. VerenaTay through this novel tells a story about one particular woman and how she treats her newborn baby. Different with other novel, Broken pictures the woman who lives in different world than us, a human. It is interesting to see how VrenaTay pictures that woman acts and somehow lives after she was dead, how a woman escapes from subversive condition and move toward dominant one by leap through the limit of life and death. Furthermore, that woman tries to deconstruct any feminist theory about maternal instinct by doing something bizarre and illogical. I will try to analyze how the protagonist in Broken deconstructs the way of thinking of feminist who supports positive maternal instinct and family although it is written based on urban legend, ghost story, and myth that comes from South East Asia.

\footnotetext{
${ }^{2}$ Ibid p. 20
}

\section{Theoritical Review}

Broken was written by VerenaTay, a Singaporean writer. VerenaTay, beside works as a writer, she also works as theater producer which is English based in Singapore. Apart from creative writing and also theater work, VerenaTay physically and vocally brings her stories in unique fashion. Although she mentions that she chose her repertoire carefully, Tay adds several twists inside her story aside from its strong character and also original tales creativity. Aside from Broken, VerenaTay successfully creates many stories which have been published worldly such as In the Company of Women: Selected Plays (2004), In the Company of Heroes (2011) and also Victimology (2011). ${ }^{3}$ Several of her other stories also published inside anthologies such as in Rainbow Feast: New Asian Short Stories (2010), More than Half the Sky: Creative Writing by Thirty Singaporean Women (1998), and also Tumasik: Contemporary Writing from Singapore (2009).

Broken which is included in Rainbow Feast: New Asian Short Stories is one story that I have most interest on it that is written by VerenaTay. First,the story has setting which is most likely in Indonesia, more precisely in Kalimantan island at the past time. Second, I think Broken's plot of story is far more complicated than any other story in the same anthology. It takes many point of views from several of its character and combines them into one single short story. Also this short story has most uniqueness which I cannot fount in the other story in the same anthology which deals with supernatural being and heavily influenced by feminist theme in which theme that is brought by VerenaTay in most of her writing. Furthermore, it is interesting to draw a line in supernatural and also feminist theme and

\footnotetext{
${ }^{3}$ Quayum, Mohammad A. A Rainbow Feast:
} New Asian Short Stories. Singapore: Cavendish Editions, 2010. p. 301 
see how those two concept mixes in one short story.

\section{Discussion}

Broken's main protagonist is Lina who is a woman who comes from one part of region in Kalimantan. At first, Lina was a vegetable seller in some market. Then she was going out with the richest man in the country called Datuk. Datuk is how people call rich man in Malayan region. The story starts with Lina who walked aimlessly in deep forest because she was deserted by her own lover.Lina's lover is Datuk. Lina later died for having bleeding when her baby born. Then, she found herself floating in the air. It was a stage when Lina left her human form and went to supernatural being in which called ghost. In Kalimantan, when a woman died when she was giving born her baby, she is called Pontianak. After died, Lina was only thinking about how to take revenge to Datuk and his family since Datuk was married with other woman named Sophia. In the end of the story, even though Lina was returned back to her human form because of some ritual ceremony, she insisted to go back to her supernatural form and successfully took revenge to Datuk and his family. Sophia was killed by Lina and Datuk was sent to prison because he was accused as murderer in Sophia murder case. In the prison Datuk see two Pontianak who are Lina and Sophia who took their supernatural form after died when giving born to a baby.

Before turning into a ghost, Linawas seen only as commodity from Datuk's point of view. After went out together for several times and finally pregnant, Lina was deserted by Datuk. She did not even dare to go back to her village because pregnancy outside marriage was considered taboo in her village. Datuk even married again with another woman named Sophia without considering how Lina's condition at that time. According to Lucinda Marshall, this kind of violence and conflict in the connection between man and woman are necessary to maintain the domination patriarchy in the society ${ }^{4}$, although this act of violence and conflict is not permitted again nowadays. In spite of that, Datuk's violence acts are still shown in several places in Indonesia where the old customs and values are still glued in people's life. To reverse that position where Lina act as subversive and Datuk as dominant one, VerenaTay uses urban legend as an apparatus. After she died, Lina was given a chance to take her revenge and in this state, she was transforming into dominant. It is interesting how Tay pictures Lina's transformation from human into supernatural being by having omnipotent power.

The child fell beyond her reach. The trickling stream that led away from the rock pooll seemed to count the last seconds of her life as it ebbed away. Finally, she closed her eyes... Only to find myself floating above the trees.

I look at my Hands. I see a faint ouline of my limsthrought which moonbeams shine. I caress myself. I stroke only the cool night breeze. Yet I feel such energy coursing through my entire being, the energy that fills and electrifies the whole universe. How curious! How wonderful to be this immaterial being, as powerful as wind, and as omnipresent as air! $!^{5}$

That passage from VerenaTay'sBroken shows how Lina change into Pontianak from her human form. In her Pontianak form, Lina took revenge on everyone who she thought humiliating her when she was alive. It shows how Lina who in her life act as oppressed one, through the power in which she was given after she was died, came back to life to take a revenge. Everyone in her village was afraid of her. It shows how

\footnotetext{
${ }^{4}$ Marshall, Lucinda. "Women Envision Peace." Off Our Backs 38 (2008). Print.

${ }^{5}$ Quayum, Mohammad A. A Rainbow Feast:
}

New Asian Short Stories. p. 303 
Lina has changed into dominant class after she was resurrected. In the middle part of the short story, Datuk was afraid of Lina and promised to marry her after changing Lina to human again through a ritual process. But, in the end, Lina was thinking that her revenge was not enough until Datuk became as desperate as possible. After that, she was haunting Datuk's family until Sophia was dead and Datuk was sent to prison. The picture of Lina in this short story resemblesAsquith's picture of ghost woman.

Her female ghosts penetrate the defenses of (dominate) their weaker alter egos not only because of genre rules of ghostly fiction but because of a self-declared female ghost's longing for control, resulting in a power struggle ${ }^{6}$.

The characteristic of female ghost in several literary works is how they are made to break the dominating class through the alter ego of their real character. For example is in Lina's story where she was depicted as pure and kind woman at first. But after she was humiliated by Datuk who was in Dominant class, she was transformed into one manifestation of alter ego who longing for control above Datuk and everyone who were humiliating her and shaping a revenge process by equipped by omnipotent power in which she did not have when she was alive.

The second issue which I want to discuss is how VerenaTay, by using her concept of Pontianak as urban legend, was trying to deconstruct the maternal concept which is brought by second and later wave of feminists or usually called the defender of family and maternal thinking. Pontianak is depicted as a mother who is devouring her own newborn baby.

An owl calls. I look down at that pale dead baby floating in a pool of fast

\footnotetext{
${ }^{6}$ Weston, Ruth. "Woman as Ghost in Cynthia Asquith: Ghostly Fiction and Autobiography." Tulsa Studies in Women's Literature ^.Spring (1987). p. 80
}

congealing blood... o my child, my beautiful baby...

An owl calls. They will pay.

An owl calls I smile.

The smell of blood - my blood, my baby's blood - now fills my senses. What a shame t waste such vital life essence. I sweep down from the trees. I open my mouth - it has grown cavernous with many sharp teeth. I rip through flesh. I crunch through bone. I drain whatever blood that remains in the two bodies.

When there is nothing left, I am satisfied. $^{7}$

The desire of revenge inside Lina had made her forget how she should behave as a mother. This act is clearly rejects how maternal instinct should be. On the other hand, Elshtain then mentions about the failure within the maternal perspective which is the death, injury, or damage of a child through carelessness or neglect or the shunting of shaming of a child through overcontrol and domination ${ }^{8}$. Actually the death of the baby, as well as Lina was a result of shaming of a child through domination which was done by Datuk character. Shame having a child outside a marriage, Datuk banished Lina from his residence and threw her into unpopulated forest. In spite of the cause of how she and her baby died, the act of Lina when she devoured her baby was remained wrongful.

I would like to compare how the depiction of maternal instinct in Kalimantan ghost, Pontianak with Thailand ghost which is usually called Mae Naak. Both of them, according to the urban legend are woman ghosts which were died when they carried their baby. The difference is Mae Naak, which is usually made as main character in Thai theater, has a positive image as a

\footnotetext{
${ }^{7}$ Quayum, Mohammad A. A Rainbow Feast: New Asian Short Stories. p. 303

${ }^{8}$ Dietz, Mary G. "Citizenship with a Feminist Face: The Problem with Maternal Thinking. p.22
} 
ghost who still pampers her baby, very different with Pontianak image in which always devours her baby right after her resurrection.

Mae Naak, or Nang Naak, as she is also known, is iconic figure of a woman possessed by a love so powerful that it staves off death and must be contained or it will wreak havoc on society.A common version of her tale relates that she, a girl from a richfamily, married a poor boy against her parents' wishes. They wereexpecting their first child when her husband Maak was called up toserve in the military-her antipathy toward the army now attractspotential conscripts to her shrine to enlist her aid in avoiding service.After suffering the horrors of the battlefield, Maak returned home tohis wife and son, not knowing that both have died in childbirth andhave become ghosts. ${ }^{9}$

Thai people even respect Mae Naak for her strong maternal instinct which has existed and told since ancient times. They build a special temple for Mae Naak because they believe that it will bless their children by praying to her. On the contrary the picture of Pontianak is seen as a scary female ghost who would devour any newborn children. So there is old belief in both Indonesia and Malaysia that if there is a baby who died at mothers womb it is Pontianak who eats them so it contains scary image through its deconstruction toward maternal instinct it has.

\section{Conclusion}

The depiction of maternal instinct in Kalimantan ghost, Pontianak with Thailand

9 Diamond, Catherine. "Mae Naak and Company: The Shifting Duality in Female Representation on the Contemporary Thai Stage." Asian Theatre Journal 23.Spring (2006). p. 112 ghost which is usually called Mae Naak. Both of them, according to the urban legend are woman ghosts which were died when they carried their baby. The difference is Mae Naak, which is usually made as main character in Thai theater, has a positive image as a ghost who still pampers her baby, very different with Pontianak image in which always devours her baby right after her resurrection. 


\section{REFERENCES}

Diamond, C. "Mae Naak and Company: The Shifting Duality in Female Representation on the Contemporary Thai Stage." Asian Theatre Journal 23.Spring (2006).

Dietz, M. G. (1985) "Citizenship with a Feminist Face: The Problem with Maternal Thinking." Political Theory.

Marshall, L. (2008). "Women Envision Peace." Off Our Backs 38.

Quayum, M. A. (2010). A Rainbow Feast: New Asian Short Stories. Singapore: Cavendish Editions.

Weston, R. (1987). "Woman as Ghost in Cynthia Asquith: Ghostly Fiction and Autobiography." Tulsa Studies in Women's Literature ^.Spring (1987). 